\title{
Democratization Impacts on Perception Expression: A Comparative Study of Pre-1990 and Post-1990 Scenario of Tibetan Refugee Minority in Nepal
}

\author{
Achyut Aryal* and Venkatasubramanian \\ Mewar University, India
}

\begin{abstract}
This is a research article on study of democratization impacts on perception expression, a comparative study of pre-1990 and post-1990 scenario of Tibetan refugee minority in Nepal. This study explores the impacts of democratization trend in the underrepresented and historically silent community's perception expression pattern, here the Tibetan refugee of Nepal. It is clear that democratization has tremendous effects on minority's perception expression like Tibetan refugee in this study. Through content analysis and survey this research concludes the proportion of news with Tibetan refugee's expressed perception after restoration of democracy in 1990 is greater than the proportion of news with Tibetan refugees expressed perception before 1990 and the proportion of news without Tibetan refugee's expressed perception after restoration of democracy in 1990 is greater than the proportion of news without Tibetan refugees expressed perception before 1990. So the conclusion is-democratization of 1990 in Nepal has huge impacts on Tibetan refugee minority's perception expression.
\end{abstract}

Keywords: Democratization; Impacts; Minority; Perception; Tibetan refugee

\section{Introduction}

At the end of 1989, Nepal stopped registering Tibetan refugees. Of the remaining registered refugees, some 12,000 live in Kathmandu's Bouddha or in Pokhara, Baglung, and other places. China considers these refugees as illegal immigrants. From 1986 to 1996 approximately 25,000 Tibetans have taken refuge in India increasing the exile population by more than $18 \%, 30 \%$ are children seeking placement in an exile school. Refugees must travel for days in waist-deep snow, there is nowhere to find shelter, food or water in the mountain passes; many suffer frostbite, injury, death. It has been a consistent policy of Nepal that Tibet is an integral part of China. Sino-Nepal relations in political, economic and cultural spheres have grown from heights to heights since diplomatic relations was established in 1955. Occasionally, Nepal faces criticism from the U.S and some European countries as regards to its Tibetan refugee policy [1-5].

According to the latest United States State Department Human Rights Report for 2009, Tibetans repatriated from Nepal reportedly suffered torture, including electric shocks, exposure to cold and severe beatings and were forced to perform heavy physical labor. Tibetan refugees in Nepal also witnessed curtailment of freedom of expression as police imposed restrictions on demonstrations and sometimes detained demonstrators.

An estimated 20,000 Tibetan refugees in Nepal arrived between 1959 and 1989 [6-15]. Since the early 1980's, when China-Tibet opened to trade and tourism, a second exodus of Tibetan refugees have joined the Tibetan exile community in Nepal India and fleeing religious persecution, political repression, aggressive sanitization and cultural genocide $[6,10,12,16-17]$

The Chinese People's Liberation Army launched its first 'invasion' into Tibet in 1949 which is now the autonomous region of the People's Republic of China. In the years that followed the Dalai Lama's efforts to make peace with the Chinese leadership failed. On the night of March 17, 1959, the Dalai Lama took flight towards India, hoping to appeal to the international community to take action against Chinese 'aggression' in Tibet. On March 31, 1959, exhausted and seriously ill, the Dalai Lama crossed onto Indian soil. All hope for the survival of Tibet's 2,000 year old civilization lay in India with the Dalai Lama and 100,000 refugees living in India and Nepal $[12,16,17]$.

In this context these are the objectives that can be outline as for effects of 1990's democracy on news coverage of Tibetan refugee by Nepalese press and their perception:

- To know the effect of restoration of democracy in 1990 on news coverage with Tibetan refugees expressed perception by Nepalese press.

- To know the effect of restoration of democracy in 1990 on news coverage without Tibetan refugees expressed perception by Nepalese press.

Moreover, researcher in spiral of silence tradition reached just to 'fear of isolation leads towards spiral of silence'. Nobody has gone further, what happens after spiral of silence? Fear of isolation just creates spiral of silence or it goes further? No research has been found on such relation, this is main gap I got after reviewing available literature. This gap encouraged this researcher to carry out this study 'Democratization impacts on perception expression: A comparative study of pre-1990 and post-1990 scenario of Tibetan refugee minority in Nepal'. The following research questions and hypothesis have been addressed in this study:

*Corresponding author: Achyut Aryal, PhD Scholar, Mewar University, Chittorgargh, Rajasthan, India, Tel: 7065846035; E-mail: aryala4dk@yahoo.com

Received August 10, 2015; Accepted October 31, 2015; Published November 08, 2015

Citation: Aryal A, Venkatasubramanian (2015) Democratization Impacts on Perception Expression: A Comparative Study of Pre-1990 and Post-1990 Scenario of Tibetan Refugee Minority in Nepal. J Socialomics 4: 126. doi:10.4172/21670358.1000126

Copyright: () 2015 Aryal A, et al. This is an open-access article distributed under the terms of the Creative Commons Attribution License, which permits unrestricted use, distribution, and reproduction in any medium, provided the original author and source are credited. 
Q1. What is the effect of restoration of democracy in 1990 on news coverage without Tibetan refugees expressed perception by Nepalese press?

Q2. What is the effect of restoration of democracy in 1990 on news coverage of Tibetan refugee from agency source by Nepalese press?

\section{Hypothesis}

H1: The proportion of news with Tibetan refugee's expressed perception after restoration of democracy in 1990 will be greater than the proportion of news with Tibetan refugees expressed perception before 1990.

H2: The proportion of news without Tibetan refugee's expressed perception after restoration of democracy in 1990 will be greater than the proportion of news without Tibetan refugees expressed perception before 1990.

\section{Limitations of the Study}

This study has several limitations. First, perceptions expression pattern of Tibetan refugee may not equate actual situation of the specific media coverage as well as Tibetan refugee's condition. Second, data were collected on a specific group of people and belonging to a specific work environment. Third, because of the legal procedure (foreign policy of Nepal is One-China) during the survey period, data were collected from Kathmandu and three refugee settlements only by using volunteer researcher. Lastly, the scope of this study is also limited in terms of budget and time available for this kind of study, so was focused only in the content analysis of 3 newspapers of 6 years' time frame before and after restoration of democracy. The research has some other limitations: The study includes only content analysis of three broadsheet daily English newspaper from Kathmandu, As compared to the total number of the potential print, the sample size is small. The survey study includes only of three Tibetan refugee camps of capital city Kathmandu (Boudha, Swyambhu and Jawalakhel). As compared to the total number of the potential respondents, the sample size is small. The study gives more focus to the quantitative study than qualitative study. Further for data analysis only the Microsoft Word 7 has been used; and data are calculated through simple tables, figures, percentages, frequencies etc. For testing, only the correlation and mean value used.

\section{Lack of Democratization Effects Study on Minority Perception}

The available all literature are of media effects is repeatedly focused on three-stage progression respectively amazing a theory of strong effects guided by a availability of earlier research and recent model of minimal effects guided by yet next availability and a new findings of strong effects premises. Conclusion is that such a nature is both historically not focused and that this forgotten approach of democratization effects on media, press and news may prove to be a significant gap to further theoretical refinement and progress in the field. What has been achieved yet was not proper!

All scholars focused only on the media effects approaches on society. The effects of democracy on news coverage approach have been left till [18-32].

The availability of thousands published textbooks; scholarly articles and reference book entries that attempt to summarize and organize the media effects field [18,22,25,26,29,31-45]. But lacking approach is still there, and that is 'effects of democracy on news coverage'. This research will hope to fulfill this gap.

The restoration of multi-party democracy in 1990 ushered in a new era of liberalism, freedom and pluralism in the public sphere. Following the promulgation of the new constitution, sweeping legislative and legal reforms have been introduced, ensuring freedom and dignity of the fourth estate [46].

Kharel [7-8] write "with the restoration of multiparty democracy in 1990, the media environment in Nepal took a dramatic turn". "The issue of freedom of speech and expression first found specific recognition in the country's first Constitution in 1948 but it was never implemented. All subsequent four constitutions in 1951, 1958, 1963 and 1990 made similar recognition with varied wordings and provisions. The acts that followed were of different nature and pattern however". The interim constitution 2006 has followed the same pattern of before [16-17].

All the available research on Tibetan refugee in Nepal focused their research angle on humanity, health, camp management in relation to superpower nations supports and the political dilemma. No researchers till focused on the perception expression pattern of Tibetan refugee available in Kathmandu. This research will hope to fulfill this gap.

\section{Methodology}

\section{Method I: Content Analysis}

To this end, the study design used in the research work for data collection was content analysis. Importantly, communication research content analysis is regarded a formal system which is systematic and objective for extracting all forms of communication contents. According to Berelson [33], content analysis is a research technique for the objective systematic description of manifest content of communication. Similarly, Kerlinger defines content analysis as a method of studying and analyzing communication in a systematic, objective and quantitative manner for the purpose of measuring variables cited in ref. [47,48]. Therefore, content analysis was used in this study as a tool to extract data from the content of the selected newspapers of respective years. This was done by analyzing the frequency and prominence or importance as well as direction/slant of news on Tibetan refugee activities as content categories. More so, the unit of measurement and news analysis included features, news stories, editorials, special reports and sources of news, etc.

For the purpose of this study, 6 different years (1959, 1974 and 1989 of before restoration of democracy and 2004, 2008 and 2012 of after restoration of democracy) were selected by chance; 15 years differences for pre-1990 and 4 years for post 1990. Further, 3 national dailies, of each year, totally 9 from pre-1990 and similarly 9 from post-1990, of each year 3 , totally 18 were selected. It is assumed that the declaration of democracy in 1990 heavily affected Tibetan refugee News coverage and further people's movement in 2006 and end of monarch also affected Tibetan refugee news coverage by Nepalese press.

The reasons for the selection of these newspapers were based on their national coverage, popularity, readership rating and large extent of specific positions on national issues. More so, a probability sampling technique was adopted for the selection of the years to be studied each 3 from two phases, pre and post 1990 time frame. This is because the sampling technique allows every unit of the population an equal chance of being selected from the sample.

For the purpose of emphasis, the years selected were arrived at using the format. Essentially, all the years of two phases were assigned identical cards, for the selection of the sample. The identical cards were 
placed in enclosed containers (two) making them in ball shape with a lid whenever the balls were reshuffled. As the first container was opened after been reshuffled, the first ball that was picked was 1959 followed by 1974 which was the second card. Same had been done with second container of after 1990. This particular method is referred to as 'hand drawing balloting'. The method/technique gives equal opportunity or chance to issues selected each year without any form of bias.

\section{Method II: Survey}

The study was based on quantitative methods, but it also applied qualitative methods to cross check the findings received from the quantitative methods.

The sampling population for this study was comprised of Tibetan refugee community of different camps. Total Population of the Tibetan refugee living in Nepal as per Tibetan Demography survey in exile done in the year 2009 (TDS) is 13514 consisting of total male 6543 and female 6971. But certain media and organization says that Tibetan population in Nepal is around 20000. Total population of the demography survey done in the year 1998 is 12224 with male population 6319 and female population 5905. According to the Demography survey 2009, there are altogether 3265 Tibetan household in Nepal, number of normal household is 3083 and 182 household consist of institutional household like (school, monastery, institution, elders home etc).

The required sample size for each domain was estimated using the following expressions with the assumption of a 95 percent confidence interval (z), 4 percent margin of error (e) and 50 percent prevalence rate $(\mathrm{p})$.Where, $\mathrm{z}$ is the factor needed to achieve the 95 percent level of confidence (1.96), $\mathrm{p}$ is the prevalence rate for the key indicator $(0.5)$ and $e$ is the margin of error to be tolerated (0.06).

Under these assumptions, the total number of required samples turns out to be 376 and rounding this figure upward becomes 400 . But, during the pretest time response rate was $60 \%$ after caring pretest and its response rate thus, altogether 700 samples were drawn from different groups of respondents from three refugee camps. So that proper result will be carried out to get generalization. This number was allocated to different camps and geography.

The study was conducted in Nepal, specifically in the Kathmandu. The Kathmandu Metropolis constitutes the capital city of Nepal and therefore the political and administrative nerve center of the country and this was where the activities of the researcher were concentrated. The target subjects for the research were Tibetan refugee living now in Kathmandu. This was because my research demands them to opine their perception expression pattern. Through convenience sampling technique, three out of 18 Tibetan refugee camps in Nepal were chosen; these are: Baudha, Jawalakhel and Swyambhu. Data collected for use in this research were collected through content analysis, questionnaire and other documentary sources.

\section{Reliability}

The entire news articles of two newspapers were coded and doublecoded by the researcher himself to determine intra-coder reliability. Moreover, Mrs. Trishna Acharya, a MA student in Department of Journalism, Tribhuban University coded a random sample of $10 \%$ of newspapers to evaluate the inter coder reliability. In this connection, Holsti's formula: $(2 \mathrm{M} / \mathrm{N} 1+\mathrm{N} 2)$ was applied to measure inter - coder reliability (Table 1).

In the following Tables 1 and 2 stands for interceder and intra coder reliability. The researcher himself as inter coder-1 carried out content

\begin{tabular}{|c|c|c|c|c|}
\hline \multicolumn{3}{|c|}{ Coverage Pattern } & \multicolumn{2}{|c|}{ The Himalayan Times National Daily 2012 AD } \\
\hline \multirow{3}{*}{$\begin{array}{l}\text { Perception/ } \\
\text { Quotes of } \\
\text { TR in news }\end{array}$} & \multirow[t]{2}{*}{$\begin{array}{l}\text { Quotes } \\
\text { of TR }\end{array}$} & $\begin{array}{l}\text { D.L. \& } \\
\text { E.G. }\end{array}$ & 14 & 15 \\
\hline & & $\begin{array}{l}\text { General } \\
\text { TR }\end{array}$ & 1 & 0 \\
\hline & \multicolumn{2}{|c|}{ Without TR } & 92 & 92 \\
\hline Total & & & 107 & 107 \\
\hline \multirow{2}{*}{\multicolumn{3}{|c|}{ Coverage Pattern }} & \multicolumn{2}{|c|}{ The Himalayan Times National Daily 2012 AD } \\
\hline & & & Inter Coder 1 & Inter Coder 2 \\
\hline \multirow{3}{*}{$\begin{array}{l}\text { Perception/ } \\
\text { Quotes of } \\
\text { TR in news }\end{array}$} & \multirow[t]{2}{*}{$\begin{array}{l}\text { Quotes } \\
\text { of TR }\end{array}$} & $\begin{array}{l}\text { D.L. \& } \\
\text { E.G. }\end{array}$ & 14 & 15 \\
\hline & & $\begin{array}{l}\text { General } \\
\text { TR }\end{array}$ & 1 & 0 \\
\hline & \multicolumn{2}{|c|}{ Without TR } & 92 & 92 \\
\hline Total & & & 107 & 107 \\
\hline \multirow{2}{*}{\multicolumn{3}{|c|}{ Coverage Pattern }} & \multicolumn{2}{|c|}{ The Himalayan Times National Daily 2012 AD } \\
\hline & & & Inter Coder 1 & Inter Coder 2 \\
\hline \multirow{3}{*}{$\begin{array}{l}\text { Perception/ } \\
\text { Quotes of } \\
\text { TR in news }\end{array}$} & \multirow[t]{2}{*}{$\begin{array}{l}\text { Quotes } \\
\text { of TR }\end{array}$} & $\begin{array}{l}\text { D.L. \& } \\
\text { E.G. }\end{array}$ & 14 & 15 \\
\hline & & $\begin{array}{l}\text { General } \\
\text { TR }\end{array}$ & 1 & 0 \\
\hline & \multicolumn{2}{|c|}{ Without TR } & 92 & 92 \\
\hline Total & & & 107 & 107 \\
\hline
\end{tabular}

Where:

Number of coding decisions on which the two coders agreed.

$\mathrm{N} 1=$ Number of coding decisions made by the coder 1 (Researcher)

$\mathrm{N} 2=$ Number of coding decisions made by the coder 2

Table 1: Inter-coder reliability.

\begin{tabular}{|c|c|c|c|c|}
\hline \multicolumn{3}{|c|}{ Coverage Pattern } & \multicolumn{2}{|c|}{ Gorkhapatra National Daily 1974 AD } \\
\hline \multirow{3}{*}{$\begin{array}{l}\text { Perception/ } \\
\text { Quotes of TR in } \\
\text { news }\end{array}$} & \multirow[t]{2}{*}{$\begin{array}{l}\text { Quotes of } \\
\text { TR }\end{array}$} & $\begin{array}{l}\text { D.L. \& } \\
\text { E.G. }\end{array}$ & \begin{tabular}{|l|} 
Inter Coder 1 \\
1
\end{tabular} & $\begin{array}{l}\text { Inter Coder } 2 \\
1\end{array}$ \\
\hline & & General TR & 0 & 0 \\
\hline & \multicolumn{2}{|l|}{ Without TR } & 36 & 36 \\
\hline Total & & & 37 & 37 \\
\hline \multirow{2}{*}{\multicolumn{3}{|c|}{ Coverage Pattern }} & \multicolumn{2}{|c|}{ Gorkhapatra National Daily 1974 AD } \\
\hline & & & Inter Coder 1 & Inter Coder 2 \\
\hline \multirow{3}{*}{$\begin{array}{l}\text { Perception/ } \\
\text { Quotes of TR in } \\
\text { news }\end{array}$} & \multirow[t]{2}{*}{$\begin{array}{l}\text { Quotes of } \\
\text { TR }\end{array}$} & $\begin{array}{l}\text { D.L. \& } \\
\text { E.G. }\end{array}$ & 1 & 1 \\
\hline & & General TR & 0 & 0 \\
\hline & \multicolumn{2}{|l|}{ Without TR } & 36 & 36 \\
\hline Total & & & 37 & 37 \\
\hline \multirow{2}{*}{\multicolumn{3}{|c|}{ Coverage Pattern }} & \multicolumn{2}{|c|}{ Gorkhapatra National Daily 1974 AD } \\
\hline & & & Inter Coder 1 & Inter Coder 2 \\
\hline \multirow{3}{*}{$\begin{array}{l}\text { Perception/ } \\
\text { Quotes of TR in } \\
\text { news }\end{array}$} & \multirow[t]{2}{*}{$\begin{array}{l}\text { Quotes of } \\
\text { TR }\end{array}$} & $\begin{array}{l}\text { D.L. \& } \\
\text { E.G. }\end{array}$ & 1 & 1 \\
\hline & & General TR & 0 & 0 \\
\hline & \multicolumn{2}{|l|}{ Without TR } & 36 & 36 \\
\hline Total & & & 37 & 37 \\
\hline
\end{tabular}

Table 2: Inter-coder reliability.

analysis of $10 \%$ newspapers among 18 populations. Mrs. Trishna Acharya, as a inter coder-2, a MA student in Department of Journalism and Mass Communication, Tribhuban University coded a random sample of $10 \%$ of newspapers to evaluate the inter-coder reliability.

When it was applied by the researcher in the light of Holsti's formula, it was found that inter-coder agreement was (0.9999) 99.99 Percent. Similarly all the news of the newspapers were coded and 
double coded by the researcher himself in order to determine intra coder reliability. After the assessment of coding -1 and coding -2 , it was calculated news (144) from two newspapers.107 from The Himalayan Times National Daily 2012 AD and 37 from Gorkhapatra National Daily 1974 AD; $10 \%$ newspapers out of 18 populations of total selected 6 different years. Selection was done with random sample method. Difference of coding decision was found only in one story (But not on all variables). According to the calculation intra coder reliability was found (0.9999) 99.99 percent (Table 2).

\section{Validity}

Validity is related to reliability, but they are not the same thing. A measure can be reliable but not valid. It cannot be valid if it is unreliable. Validity presumes reliability; external validity-the ability to generalizepresumes internal validity. Reliability guarantees that a measure is consistent, stable, and dependable; internal validity establishes whether measures are actually measuring what they are intended to measure. To make a case for the internal validity of their measures, researcher use one or more assessment techniques [49].

Wimmer and Dominick $[47,48]$ say validity is intimately connected with the procedures used in the analysis. If the sampling design is faulty, if category overlaps, or if reliability is low, the result of the study probably possesses little validity. Additionally, the adequacy of the definitions used in the content analysis bears directly on the question of validity. Several different methods are used in content analysis to assess validity. The most common is face validity, which is appropriate for some studies. It is recommended, however, that the content analysis also examine other methods to establish the validity of a given study $[47,48]$.

Wimmer and Dominick [47-48] say face validation technique assumes that an instrument adequately measures what it purports to measure if the categories are rigidly and satisfactorily defined and if the procedures of the analysis have been adequately conducted.

A measurement instrument is valid when the conclusion from the scores of that instrument is in agreement with the measurement aim of that instrument. When two different measurement instruments with the same measurement aim lead to the same conclusions in the same situations, this can be taken to be a strong indication of the validity of the scale used. Panel of Experts: Validity of the research instruments was carried out sharing the instruments among the panel of experts. During the piloting, the questionnaire was sent to six experts and practitioners including thesis supervisor for their comment and recommendations. Based on their suggestions, the questionnaire was revised. It helped in enhancing the content validity of the instruments.

Translation-back-translation: The Content of Nepali language newspapers was first developed in English and translated into Nepali. The Nepali version was again translated into English. The translation was carried out by a freelance translator. The rationale behind translating and back-translating was to check its validity. If the English translation was the same as the original, it was considered as valid. If there were some deviation, the researcher had to discuss it with the translator to find the cause and improve the content again.

There was slight variation between the original version and the translated version. The researcher incorporated the suggestions made by the translator in the final version of the content in content analysis.

Regarding external validity or the generalization of the result of this work, the researcher had emphasized right from the sampling design.

\section{Conceptual Framework}

The basic conceptualization for this study has been outlined like this: by fear of isolation minorities like Tibetan refugee do not give perception openly in press on controversial issues; they imposed their voice within self. And this action starts negative reaction in rapid way. After certain period of imposition it bursts with collective manner and which affects everything, basically three aspects in relation to Tibetan refugee:

\section{Effects on Society \\ 2. Effects on Media \\ 3. Effects on Tibetan Refugee themselves}

The figure can be outlined like this in sum: (Figure 1).

To get such result I've structured the study in two sections. First, study of news coverage before restoration of democracy in 1990 and second, study of news coverage after restoration of democracy in 1990. Very clear, 1990's restoration of democracy is demarcation line to judge the impacts on news coverage pattern of Tibetan refugee by Nepalese press. It is logical to say the comparison of pre 1990 news coverage pattern with post 1990 scenario reveals the impacts with clear picture for the research topic effects of 1990's restoration of democracy on news coverage of Tibetan refugee by Nepalese press. To get such result it has been conceptualized to use two reasoning methods in this research. Namely they are:

\section{Inductive Reasoning (Induction)}

Through this reasoning method it has been found out that Tibetan refugee always remained silent in Nepalese press. They didn't expressed their opinion in Nepalese press in 1959 particularly in the study samples, Samaj national daily, The commoner national daily and Motherland national daily. In 1974 particular case to the situation remained same, Naya Samaj national daily, Gorkhapatra national daily and Hamro Des national daily; all in all they have found remaining

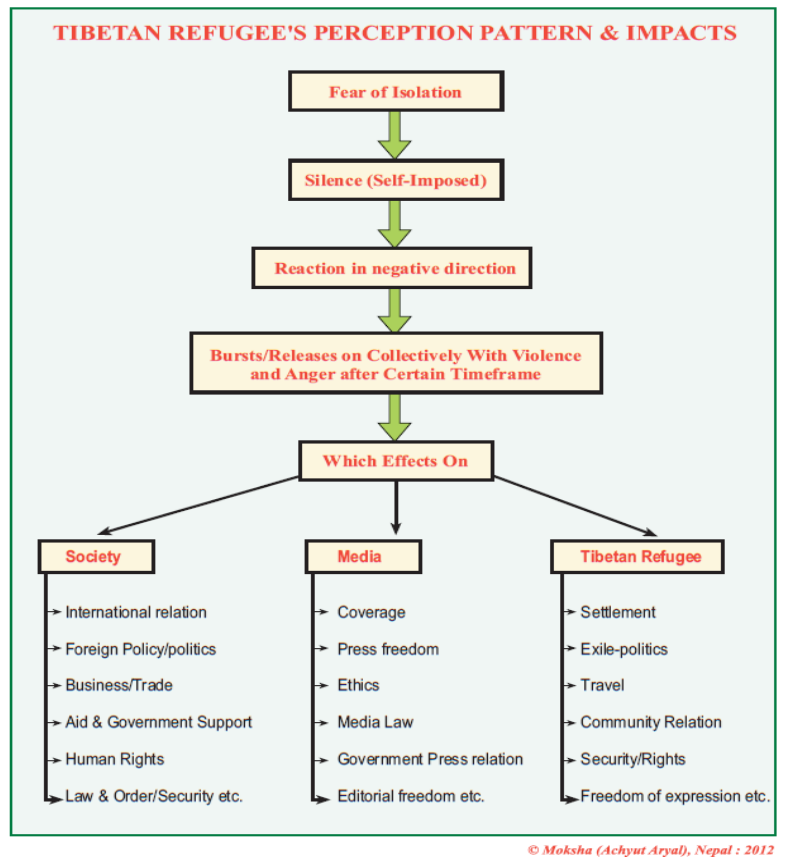

Figure 1: Conceptual framework in figure. 
silent! Another particular case of 1989 and the particular the then sampled media, Samaj national daily, Dainik Siddartha national daily and Gorkhapatra national daily; also found with previous trend, almost all Tibetan refugee remained silent in press.

In 1990 a democratic change has occurred in Nepal. It has been calculated the perception expression pattern of Tibetan refugee in Nepalese press with different sampled particular cases. Of 2004 AD; The Himalayan Times national daily, The Rising Nepal national daily and The Kathmandu Post national daily were studied. Result was same, Tibetan refugee remained silent in Nepalese press after restoration of democracy in 1990 too. Again of $2008 \mathrm{AD}$, as particular cases The Himalayan Times national daily, The Rising Nepal national daily and The Kathmandu Post national daily were studied. Result remained here to the same, Tibetan remained silent in Nepalese society. At last of 2012 $\mathrm{AD}$, three particular press, The Himalayan Times national daily, The Rising Nepal national daily and The Kathmandu Post national daily were studied. Amazingly Tibetan here too found remained silent as like previous 50 years.

In each and every individual cases Tibetan refugee were remained silent, almost all of the long 50 years. And conclusion is that, as minority they feel fear of isolation in Nepalese society, and remained silent always. The whole evidences of different particular cases prove- it is spiral of silence, as theorized by Elizabeth Noelle Neumann in 1974 $\mathrm{AD}$.

\section{Deductive Reasoning (Deduction)}

Deductive reasoning here used in this research when inductive conclusion has been found not matched with historical development of Tibetan refugee attribute in Nepalese society. During content analysis a different map had been identified, after Lhasha plight in 1959 Tibetan refugee influxes in Nepal. In 1974, a Khampa War was occurred. In 1989, when Dalai Lama got Nobel Peace Prize, refugee started protest. In 2004 also they started protest. Again in 2008, refugee all over the world raised voices against Beijing Olympic, it was violent. In 2012 Tibetan refugee started self-immolation all over the world; including in Nepal.

So, situation seems quite opposite from what theory suggest. This research, started deductive method to analyze general spiral of silence notion on newly developed circumstances. Finally, it is got with content analysis and survey, that Tibetan refugee express their voices violently.

Historically, the same pattern was seen when they opine it in society. Here, new theory has been proved that; fear of isolation of minority community leads them to spiral of violence situation. It is not spiral of silence as assumed by Elizabeth Noelle Neumann. It is spiral of violence. A cycle of silence- violence situation has been found after the use of induction and deduction reasoning for the study. Finally, the results have been interpreted and analyzed with the help of different tables, graphs and statistical tools.

\section{Perception Expression Pattern}

Kharel [7-8] says 'the media gives voice to various sections of society through one channel or another. They attract public attention, persuade people, influence their behavior and help define many issues. Access to media is an important factor for enhancing media access to readers, listeners and viewers and it is possible only in democracy.

But the result of content analysis indicates not only in autocracy, even in democracy Tibetan refugee remained silent. They never covered as quotes in comparison to their will to express in the press.
Here is a table of data which reveals about Tibetan refugee's perception in Nepalese press in authoritarian era and in democracy (Table 3).

Both the available data proves that Tibetan refugee community in Nepal is not speaking in front of Nepalese press. Nepalese press quote except Tibetan refugee while dealing with Tibetan refugee news. Nepalese media are reporting the Tibetan refugee matter without quotes from concerned sector? Is it fair? Why it is happening? Who are responsible for it? Do Tibetan refugees speak in Nepalese press? Or presses are being biased for quoting them? What is the reality? As a media researcher I felt responsibility to search it. The following quote pattern results definitely forces everyone to search why? (Figure 2).

Kharel [7-8] says use of quotes is a very widely accepted practice among journalist. Without quotes, news stories are generally not complete; they add life to a news item. In case of Tibetan refugee reporting this does not apply. Another result more surprisingly presents the perception expression pattern of Tibetan refugee in Nepalese press: (Figure 3)

Prajapati [50] showed that The Rising Nepal has used 0 quote of Tibetan refugee in 2008. The same result I've got during my content analysis of whole editions of 2008. Moreover the figure above says perception of general Tibetan refugee were very few in comparison to Dalai Lama and exile government. It is amazing result in itself.

\begin{tabular}{|c|c|c|c|}
\hline \multirow{3}{*}{$\begin{array}{l}\text { Year } \\
\text { A.D. }\end{array}$} & \multicolumn{3}{|c|}{ Perception Pattern/Quotes of Tibetan Refugee(TR) in Press } \\
\hline & \multicolumn{2}{|c|}{ Total news with a quotes on TR } & \multirow{2}{*}{$\begin{array}{c}\text { Total news without } \\
\text { TR quotes }\end{array}$} \\
\hline & $\begin{array}{l}\text { Quotes of } \\
\text { General TR }\end{array}$ & $\begin{array}{l}\text { Quotes of Dalai Lama and } \\
\text { Exile Govt. representative }\end{array}$ & \\
\hline 1959 & 0 & 3 & 60 \\
\hline 1974 & 0 & 1 & 50 \\
\hline 1989 & 0 & 4 & 47 \\
\hline 2004 & 1 & 6 & 107 \\
\hline 2008 & 6 & 30 & 318 \\
\hline 2012 & 2 & 16 & 128 \\
\hline Total & 9 & 60 & 710 \\
\hline
\end{tabular}

Table 3: Perception expression pattern.

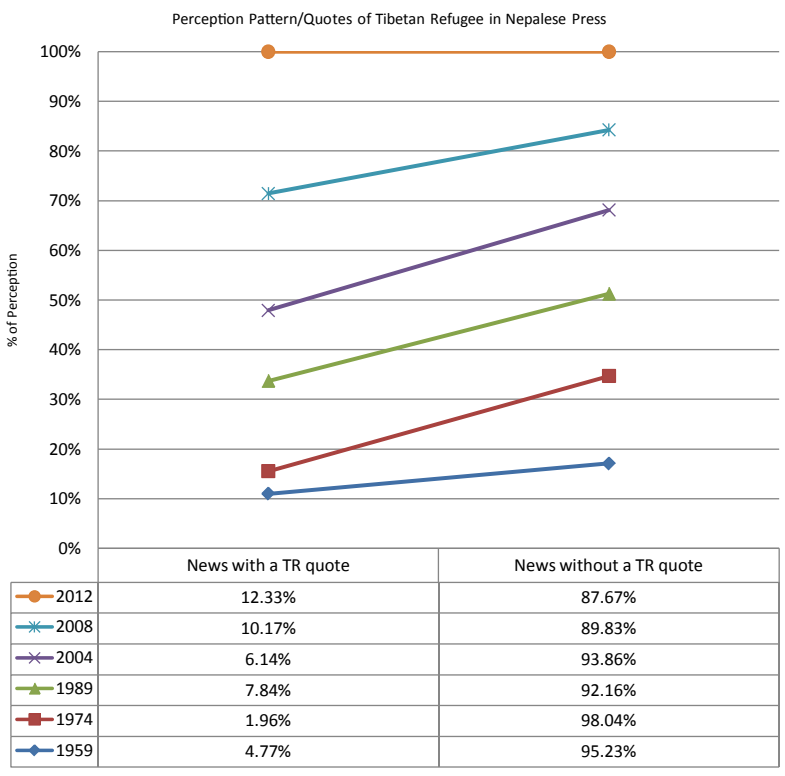

Figure 2: Perception expression variety. 


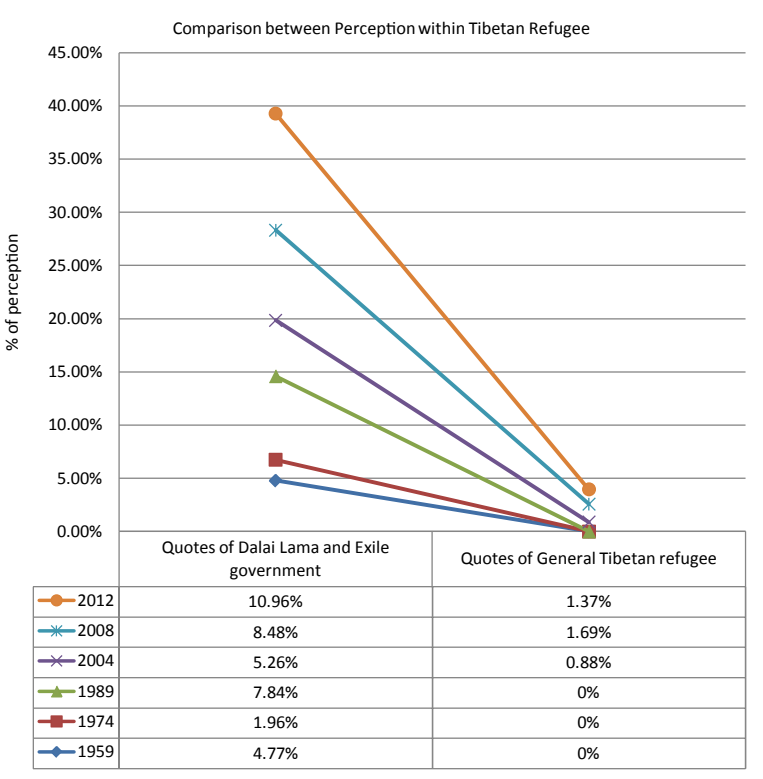

Figure 3: Democratization impacts on Perception expression

\section{Effects of Democracy on Perception Expression: A Test}

On the basis of data available for quotes the expected frequency corresponding to the number time period and types of news quotes would be 14.615 . The $\chi^{2}$ analysis of news with Tibetan refugee quotes table data of between before and after restoration of democracy in 1990 results $\sum\left(\mathrm{O}_{\mathrm{ij}} \mathrm{E}_{\mathrm{ij}} / \mathrm{E}_{\mathrm{ij}}\right)=4.164$. Where 69 news with a TR quote, and 710 news items without a TR quote $s$ with total 779 examined. Here in this case degree of freedom is $(\mathrm{c}-1)(\mathrm{r}-1)=1$; and the table value of $\chi^{2}$ for 1 degree of freedom at $5 \%$ level of significance is 3.841 . So, the calculated value of $\chi^{2}$ is much higher than this table value which means that the calculated value cannot be said to have arisen just because of chance. It is significant. Hence, the $\mathrm{H}_{0}$ hypothesis doesn't support. This means that $\mathrm{H}_{1}$ : the proportion of news with Tibetan refugee's expressed perception after restoration of democracy in 1990 will be greater than the proportion of news with Tibetan refugees expressed perception before 1990. And the proportion of news without Tibetan refugee's expressed perception after restoration of democracy in 1990 will be greater than the proportion of news without Tibetan refugees expressed perception before $1990\left(\mathrm{H}_{1=} \mu<\mu_{2}\right)$ has been accepted.

\section{Collective Aggression: Before and After Democracy}

My research during content analysis revealed that: after remaining certain period as in silent mood, they'd gradually start to speak and that is not in press but with collectively in open society. This has been being heavily covered by Nepalese press time and again in their news and views genres. Some of the major collectively expressed evidence found from content analysis in between pre and post restoration of democracy in 1990 was outlined like this (Table 4).

After such amazing result I've raised some major questions in my research: now again what is it? Is spiral of silence not the end? Or what, is it the beginning? Yes, the evidence says it is the beginning not the end. Imposed wish by self-compelled them to express their individual perception collectively after certain time frame, usually when they felt safe for the opinion climate. Most on those periods Nepal seems to be near on serious internal affairs (crisis). The picture was like this (Table 5).
The following survey results also indicate the spiral of silence is not the end but it is a good beginning. Minority perception does not stop only being spirally silence but it starts from there to reach at violence. Here are recent perceptions available how it takes formation to circle from spiral of silence to spiral of violence, a continued cycle:

\section{Findings}

The research question -what is the democratization impact on perception expression of Tibetan refugees? The summary of result of these research questions is as follows:

Among 779 news items of before and after restoration of democracy $11.59 \%$ belongs to news with a Tibetan refugee quotes before 1990 and the after 1990 's share is $88.41 \%$. Likewise news without a Tibetan refugee quote had been found $22.11 \%$ of before 1990 and $77.89 \%$ belongs to after 1990. 86.67\% news of Nepalese press had been found with quotes of Dalai Lama and exile-government regarding to Tibetan refugee news after 1990 similarly 13\% news had been found with Dalai Lama and Tibetan Government in Exile's quote before 1990. General Tibetan refugee's quote had been started to use by Nepalese press just after restoration of democracy in 1990. No quotes had been found before restoration of democracy in News of Nepalese press.

Before 1990 there is $4.85 \%$ quotes or perceptions of Tibetan refugee had been published in Nepalese press as coverage but after 1990 quote of Tibetan refugee in news had been found slightly in change as $9.93 \%$ in share. It's a great shift in opinion priority of Tibetan refuge by Nepalese press.

There was $95.15 \%$ news of Tibetan refugee that had been found without a quote from Tibetan refugee before 1990 but the rate had gone changed after 1990 with figure $90.07 \%$ quote of others then the Tibetans in Tibetan refugee news.

After 1990 share on quote of Dalai Lama and exile-government representative had been found $85.25 \%$ but the rate was very high $100 \%$ before 1990. It means Total share of had been under Dalai Lama's voice before 1990 on Nepalese as Tibetan refugee's voice, no other general Tibetan used to get chance to quoted by Nepalese press before. 1990's restoration of democracy was significant event for Tibetans in this aspect.

There had been found $0 \%$ quotes of general Tibetan refugee before

\begin{tabular}{|l|l|l|}
\hline S.N. & Year & Collective Perception \\
\hline 1. & 1959 AD & Tibet Uprising and plight for Exile \\
\hline 2. & 1974 AD & Khampa war, Mustang \\
\hline 3. & 1989 AD & Tibet Uprising-Il and Celebration of Nobel Peace Prize \\
\hline 4. & 2004 AD & Free Tibet Movement and Protest in Kathmandu began \\
\hline 5. & 2008 AD & Beijing Olympic and Tibet Uprising( Free Tibet) \\
\hline 6. & $2012 \mathrm{AD}$ & Self-Immolations (Apx. 200) \\
\hline
\end{tabular}

Table 4: Collectively Expressed Aggression by Tibetan Refugee.

\begin{tabular}{|l|l|l|}
\hline S.N. & Year & Internal crisis \\
\hline 1. & 1959 AD & King Mahendra vs. political parties for Panchayat \\
\hline 2. & 1974 AD & King vs. political Parties for Referendum \\
\hline 3. & 1989 AD & $\begin{array}{l}\text { King Birendra vs. political parties for restoration of } \\
\text { democracy }\end{array}$ \\
\hline 4. & 2004 AD & King Gynendra vs. political parties for Republic \\
\hline 5. & 2008 AD & CA Election and new constitution \\
\hline 6. & 2012 AD & Failure of CA and with impunity \\
\hline
\end{tabular}

Table 5: Aggression by Tibetan Refugee, Linkage with Internal Crisis of Nepal. 
1990's democracy in Nepalese press while covering the news. Shift had been found on quote of general Tibetan refugee with figure $14.75 \%$ on total share of quotes by refugee. This indicates Tibetan refugee's perceptions had gone slightly up as coverage volume in Nepalese press after 1990.

These facts prove that restoration of Democracy in 1990 is useful for Tibetan refugee to express their perception in Nepalese press as coverage.

\section{Perception Expression Pattern 2012: Survey}

The research question 8 was "What is the perception expression pattern of Tibetan refugee in Nepalese society?" The summary of result of this research question is as follows:

Tibetan refugee, who stays now in different camps in Nepal, will to express in Nepalese press. Survey result shows $85.86 \%$ Tibetan refugee will to express the voices in Nepalese press. Tibetan refugee $14.14 \%$ says they are not interested. Tibetan refugee staying now in Nepal says, their voices were never taken by the media. Tibetan refugee $100 \%$ said, their voices never been taken by Nepalese press.

There are $30.43 \%$ Tibetan refugee who tolerated injustice but a huge majority $69.57 \%$ did not enjoyed it. They never tolerated the injustice. There are $86.71 \%$ Tibetan refugee who have experience of participating in a protest. Another $27.57 \%$ refugee said they have no experience of participating in a protest ever. The data result indicates that, Tibetan refugee available in Nepal is interested to express perception in press but they did not have had the chance to do so. They never got coverage, in other word. Again, Tibetan refugee in majority level said they never enjoyed injustice. And the result was that $86.71 \%$ refugee participated in protest. A violent move time and again.

There are $85.57 \%$ Tibetan refugee who use news media to see activities of exile government and politics worldwide. Another $14.43 \%$ Tibetan said they are neutral on it. They use media by different way. This indicates majority refugee available in Kathmandu is interested in activities of exile government. Exile government network available in Nepal engaged in protest, campaign and violence activities always. They involved in Free Tibet movement, which is against law in Nepal.

There are $15.29 \%$ Tibetan refugee who are interested to stop freedom movement in Kathmandu. The cause behind it is that to live and stay fearlessly in Kathmandu. Against it, $84.71 \%$ Tibetan refugee are not interested to do so. It means they want freedom movement in any cost in Kathmandu. It indicates, Tibetan refugee living in Nepal want violence in the name of freedom. There are $14.43 \%$ Tibetan refugee who are agreed on not to speak against government and its foreign policy, even in press. But $71.43 \%$ Tibetan are not ready to do so. What does it mean? They want violence in any cost. Doesn't it?

There are $86.14 \%$ Tibetan refugees, staying in Kathmandu said; they are disagreed to remain silent within Tibetan camps. Very few are agreed on it, but it is very low in number $13.86 \%$. It indicates that Tibetan refugee available in Nepal, in majority, wants violence here in the name of freedom.

All Tibetan refugees are agreed on not to going against locals of Kathmandu. $100 \%$ are agreed on local people's support for freedom movement. They want to make good relationship with locals. It indicates that they have a fear of isolation, fear of isolation from the Nepalese community. There are $85.15 \%$ Tibetan refugee who don't want to remain silent and depart from Kathmandu living rest of the community here in Nepal. Few are agreed on it, the $14.86 \%$ just. It indicates that, in any cost Tibetan refugee want to stay in Kathmandu, speaking and raising voices living with community as a whole.

There are no refugees ready to remain silent in press where majority Nepalese are in society. $100 \%$ refugees are disagreed on 'It is better that community with less population should never speak in press that is functioning in majority's community.' It indicates Tibetan in Kathmandu is against silence. In any cost this minority wants to speak.

There are $85.61 \%$ Tibetan refugee who said they are fully agreed that 'when a person suppress their feelings and wish they suffer a lot. When a person suppress their opinion and remain silent also suffer a lot'. Few refugee, 14.43 are disagreed on it. But they are less in number.

Again, $71.42 \%$ Tibetan refugee said they are agreed 'when they suppress their feelings and voice day by day it hurts them and they become angry.' Less, $28.58 \%$ are disagreed just. It indicates dominating the perception wish of Tibetan refugee made them violent day by day. The main reason behind Tibetan aggression was the domination on perception by refugee themselves due to different reason. The main one was fear of isolation.

There are $57.57 \%$ Tibetan refugee who said for security reason, they try to remain without speaking. But here too, $28.43 \%$ disagreed and other $14 \%$ remained neutral.

On the other hand, $83.86 \%$ Tibetan refugee don't want to be isolated from Nepalese community. They have a fear of isolation. They try to remain silent, but only for few times, not always. But not all; $16.14 \%$ are not afraid with isolating from the Nepalese community; they are ready to depart even. It is more violent.

There are $86 \%$ refugees who can't remain silent in unjust condition long time. Remaining $14 \%$ can tolerate it. Means, majority never tolerate injustice over them.

There are $43.57 \%$ Tibetan refugee seek opportunity or chance to express their anger. Another $13.57 \%$ remain neutral on it and rests of the $42.85 \%$ Tibetan refugee are never seeking opportunity. This indicate, in any cost, Tibetan refugee available in Kathmandu want to speak. They want to run protest and fight for freedom here in any cost. They want violence. On such situation, all refugee $100 \%$ are against to begin protest alone. Tibetan refugees never are interested to run the protest single. Then what will be the option? There are $55.86 \%$ Tibetan refugee who engage to make other conscious which they supposed to support the conduction of protest together. But $44.14 \%$ Tibetan denied it.

There are $28.43 \%$ Tibetan refugee who are ready to give leadership to the other for violence. $28.71 \%$ refugee remained neutral to give leadership for the protest. Another $42.86 \%$ refugee is against giving leadership for the movement. It indicates that in any cost some are interested to provide leadership even. And, the result is movement took place. Leaders are few always, no? There are $41.57 \%$ Tibetan who try to gather other community member who can understand the situation and vision. $29.57 \%$ remained neutral and rests are disagreed. It means leaders of Tibetan community try to make organizational for violence in the name of freedom and protest.

There are $85.57 \%$ Tibetan refugee who are agreed on instructional formation for the movement. Rests of the $14.43 \%$ are not ready to do so. But the value of majority indicates in any cost the movement takes place.

There are 55. 57\% Tibetan refugee they said they speak in group together after such a long formation and background. 29.29\% refugee are neutral on such and rest of the 15.145 are against it. They are not 
ready to speak in group. But it doesn't matter, because the majority 55. $57 \%$ wants to speak in group. In this way, a violent movement occurred in the name of freedom and justice. No refugees are ready to tolerate injustice, for just 1 month even. There are $100 \%$ disagreements on tolerating injustice. From 100 years to months they are not ready to do it. It means all Tibetan refugees waiting for expressing against injustice over them. And definitely it takes the violent form. It is logical even.

There are $100 \%$ Tibetan refugee who want Free Tibet. Again $100 \%$ Tibetan refugee want continuation of exile government. There are $70.14 \%$ Tibetan refugee who said they love self-immolations as protest technique for Free Tibet dream. Such intention of Tibetan refugee indicate, in any cost Tibetan refugee needed Free Tibet. If it is not given, they are ready to be violent, such violent, world had seen it after 2012 in the form of self-immolations. More than 200 refugees burned themselves for Free Tibet worldwide. It is dangerous state of spiral of violence since $1959 \mathrm{AD}$. Tibetan refugee demands the freedom on 'China should stop torturing Tibetans in Tibet \& let them protest non-violently'. There are $100 \%$ Tibetans wants it. And further $85.15 \%$ Tibetan refugee demand 'Nepal Government shouldn't control Free Tibet protest in Kathmandu'. They want Free Tibet movement without anyone's interfere. The neutral share $14.86 \%$ also indicate, all Tibetan refugees intended to run Free Tibet movement without restriction.

At last, $71.86 \%$ Tibetan refugee wants to participate in Free Tibet movement or protest with whole community. Another $16.57 \%$ are interested to make small groups, various to do demonstration. And interested on single participation is $11.57 \%$. In this way on any form all Tibetan refugee are interested to do demonstration for Free Tibet.

\section{Correlation Analysis between Variables: Before 1990 and After 1990}

Test of significance from below table proves that restoration of democracy in 1990 has tremendous effects on news coverage of Tibetan refugee by Nepalese press. In all cases on below table, $\mathrm{df}=\mathrm{N}-2=1$; level of significance $=.05$ and the test $=$ two-tailed; critical value for all cases is same $=0.3531$ (Table 6).

Correlation value before 1990 in 'anti-China news coverage and perception/quotes coverage of Tibetan refugee' is $r=0.797$, statically significant. After 1990 too, significance continued with $\mathrm{r}=0.957$. Difference between $r$ value $=+16$ found between before and after restoration of democracy in 1990. It indicates the effects of restoration of democracy on these two variables. The correlation between 'oneChina angle news and news with quotes of Tibetan refugee' is statically significant for both cases. There was negative relation found before restoration of democracy in 1990, $r=-0.36$. After 1990, $r=0.999$, heavily increased the direction on positive level. The change on $r$ value +1.359 indicates the effect of restoration of democracy in 1990 on correlation between these two variables.

\begin{tabular}{|l|l|c|c|c|}
\hline S.N. & $\begin{array}{l}\text { Correlation Between } \\
\text { Variables }\end{array}$ & $\begin{array}{l}\text { Correlation } \\
\text { Before 1990 }\end{array}$ & $\begin{array}{c}\text { Correlation } \\
\text { After 1990 }\end{array}$ & $\begin{array}{c}\text { Change/Effect } \\
\text { After 1990 }\end{array}$ \\
\hline 1. & $\begin{array}{l}\text { Anti-China News } \\
\text { Coverage vs. Perception/ } \\
\text { Quotes Coverage of } \\
\text { Tibetan Refugee }\end{array}$ & $r=0.797$ & $r=0.957$ & +0.16 \\
\hline 2. & $\begin{array}{l}\text { One-China Angle News } \\
\text { vs. News With Quotes of } \\
\text { Tibetan Refugee }\end{array}$ & $r=-0.36$ & $r=0.999$ & +1.359 \\
\hline 3. & $\begin{array}{l}\text { Agency News Source vs. } \\
\text { Quotes of Dalai Lama and } \\
\text { Exile Government }\end{array}$ & $r=0$ & $r=0.99$ & +0.99 \\
\hline
\end{tabular}

Table 6: Correlation in Variables: Before 1990 vs. After 1990 AD.

\begin{tabular}{|l|l|c|c|c|}
\hline S.N. & Variables & $\begin{array}{c}\text { Mean Value } \\
\text { Before 1990 }\end{array}$ & $\begin{array}{c}\text { Mean Value } \\
\text { After 1990 }\end{array}$ & $\begin{array}{c}\text { Change/Effect } \\
\text { After 1990 }\end{array}$ \\
\hline 1. & $\begin{array}{l}\text { Quotes of Tibetan } \\
\text { Refugee in News }\end{array}$ & 2.67 & 20.33 & +17.66 \\
\hline 2. & $\begin{array}{l}\text { News Without } \\
\text { Quotes of Tibetan } \\
\text { Refugee }\end{array}$ & 52.33 & 184.33 & +132 \\
\hline 3. & $\begin{array}{l}\text { Quotes of Dalai } \\
\text { Lama and Exile } \\
\text { Government }\end{array}$ & 2.67 & 17.33 & +14.66 \\
\hline
\end{tabular}

Table 7: Mean Distribution: Before 1990 vs. After 1990 AD.

Correlation value before 1990 in 'agency news source and quotes of Dalai Lama and exile government' is absolute zero (0). It means there is no relationship between these two. But after 1990 the value of $r=0.99$, greater in volume and statically significant too. Difference on $r$ value is +0.99 . It is a big effect found of restoration of democracy in 1990 . In this way conclusion is that, democratization has tremendous effects on perception expression pattern of Tibetan refugee by Nepalese press.

\section{Mean Distribution Analysis between Variables: Before 1990} and After 1990

From table below, $\mathrm{N}=3$ in all cases, mean value for each variables can be computed. With seven different variables to calculate and test previously mentioned hypothesis, it is most. Here is detail available (Table 7).

Mean value for quotes of Tibetan refugee in news was 2.67 before 1990. After 1990, the value increased huge, 20.33. The growth on mean distribution +17.66 indicates, the proportion of news with Tibetan refugee's expressed perception after restoration of democracy in 1990 is greater than the proportion of news with Tibetan refugees expressed perception before 1990.Mean value for 'news without quotes of Tibetan refugee' was 52.33 before 1990 . After 1990, the value increased huge, 184.33. The growth on mean distribution +132 indicates, the proportion of news without Tibetan refugee's expressed perception after restoration of democracy in 1990 is greater than the proportion of news without Tibetan refugees expressed perception before 1990 . Mean value for 'quotes of Dalai Lama and exile government' was 2.67 before 1990. After 1990, the value increased huge, 17.33. The growth on mean distribution +14.66 indicates, the proportion of quotes of Dalai Lama and exile government after restoration of democracy in 1990 is greater than the proportion of quotes of Dalai Lama and exile government before 1990. In this way from all available tests above, we can say, the proportion of total perception of Tibetan refugee after 1990 is greater than the proportion of total perception before 1990 .

\section{Conclusion}

The proportion of news with Tibetan refugee's expressed perception after restoration of democracy in 1990 is greater than the proportion of news with Tibetan refugees expressed perception before 1990.The proportion of news without Tibetan refugee's expressed perception after restoration of democracy in 1990 is greater than the proportion of news without Tibetan refugees expressed perception before 1990 .

\section{References}

1. Bhatia S, Dranyi, DT, Rowley D (2002) A social and demographic study of Tibetan refugee in India. Social Science and Medicine 54: 41-442.

2. Banki S (2004) Refugee integration in the intermediate term: A study of Nepal Pakistan and Kenya. UNHCR.

3. McGranahan C (2005) Truth, fear, and lies: Exile politics and arrested histories of the Tibetan resistance. Cultural Anthropology 20: 570-600.

4. Benedict AL, Mancinib L, Grodin MA (2009) struggling to meditate: 
Citation: Aryal A, Venkatasubramanian (2015) Democratization Impacts on Perception Expression: A Comparative Study of Pre-1990 and Post-1990 Scenario of Tibetan Refugee Minority in Nepal. J Socialomics 4: 126. doi:10.4172/2167-0358.1000126

Contextualizing integrated treatment of traumatized Tibetan refugee monks. The Journal of Nervous and Mental Disease 12: 485-499.

5. Freedom to believe (2010) Protecting and promoting Article 18, freedom of religion in Tibet. Free Tibet.

6. Balakin S (2005) We Could Be Heroes: Mythico-History, Diasporic Nationalism, and Youth Identity among Tibetan Refugees in Nepal. The Interdisciplinary Journal of Study Abroad 2: 3-4.

7. Kharel B (2009) Annual report 2008. LWF, Nepal.

8. Kharel P (2006) A study of journalism. NAME, Kathmandu, Nepal 4: 178.

9. Pandey S (1999) A culture of democracy. The Kathmandu Post, kantipur publications, Kathmandu Nepal.

10. Pandey NN (2007) Comprehensive Security in South Asia. Kathmandu, Nepal.

11. Conboy K, Morrison J (2002) The CIA's secret war in Tibet. University Press of Kansas. USA.

12. Siwakoti GK (2003) Exodus of Tibetan refugees: Trail to hell. Wadham College, Oxford University. Kathmandu, Nepal.

13. Dulaney AG, Cusack DM (1998) The case concerning Tibet, Tibet's soverginity and the Tibetan's people's right to self-determination. Tibet Justice Center.

14. Dumbaugh K (2008) Tibet: Problems, Prospects, and U.S. Policy, Author, USA.

15. Conway JS, (1975) The Tibetan community in exile. Pacific Affairs 48: 74-86.

16. Aryal A (2013) Democratic Effects on News Coverage of Tibetan Refugee by Nepalese Press: A Study of Situation after Restoration of Democracy in 1990. 1: $96-120$.

17. Aryal A (2013) Spiral of Violence: A Study of the Model on Perception Pattern and Aggression Expression in Nepalese Press by Tibetan Refugee 3: 5-159.

18. Schramm W, Roberts DF (1974) The process and effects of mass communication. Urbana: University of Illinois Press 8: 122-125.

19. Noelle-Neumann E (1973) Return to the concept of powerful mass media (7thedn), Studies of Broadcasting 9: 67-112.

20. James Potter W (2011) conceptualizing media effects 61: 896-915.

21. Katz E (1987) Communications research since Lazarsfeld. Public Opinion Quarterly 51: 25-45.

22. Russell Neuman W, Lauren Guggenheim (2011) The Evolution of Media Effects Theory: A Six-Stage Model of Cumulative Research 21: 169-196

23. Everett M, Rogers, Francis Balle (1982) The media revolution in America and in Western Europe 51: 138-140.

24. Berger CR, Chaffee SH (1987). The study of communication as a science. Handbook of communication science. Newbury Park CA: Sage 15-19.

25. Delia JG, Berger CR, Chaffee SH (1987) Communication research: A history. In (1stedn), Handbook of communication science. Sage 20-98.

26. De Fleur ML (2002) Understanding mass communication (7thedn), Boston: Houghton Mifflin, USA.

27. Wartella E, Dennis EE (1996) The history reconsidered. In (1stedn), American communication research: The remembered history. Mahwah NJ: Erlbaum 169180.

28. Wicks RH, Joseph Klapper (1996) The effects of mass communication: A retrospective. Journal of Broadcasting and Electronic Media 40: 563-569.
29. Bryant J, Thompson S (2002) Media effects: A historical perspective (1stedn), Fundamentals of media effects Boston: McGraw Hill 21-64.

30. Rogers EM (2002) Intermedia processes and powerful media effects. Media effects: Advances in theory and research (2ndedn), New Jersey: Lawrence Erlbaum, Mahwah

31. Perse EM (2001) Media effects and society, Routledge Communication Series wales, England.

32. Kepplinger HM, Donsbach W, Brosius H, Staab, JF, et al. (1990) Media tone and public opinion: A longitudinal study of media coverage of media coverage and public opinion on Chancellor Kohl. International Journal of Public Opinion and public opinion on

33. Lazarsfeld PF, Berelson B (1960) The effects of mass communication. The Free Press, New York, USA.

34. Lazarsfeld PF, Berelson B, Gaudet H (1944) The people's choice: How the voter makes up his mind in a presidential campaign. University Press Columbia, New York, USA.

35. Berelson B (1952) Content analysis in communication 2: 1: 64-67.

36. McGuire WJ (1986) The myth of massive media impact: Savaging's and salvaging's. Public communication and behavior, Academic Press, London, United kingdom.

37. Chaffee SH (1977) Mass media effects Communication Research Honolulu: University of Hawaii Press. 1: 210-241.

38. Comstock G, Paik H (1991) Television and the American child 40: 2: 292-294.

39. Comstock G, Chaffee S, Katzman N (1978) Television and human behavior New York: Columbia University Press.

40. Comstock G (1978) Television and human behavior: The research horizon, future and present. Columbia University Press, New York, USA.

41. Lang GE, Lang K (1981) Mass communication and public opinion, Social psychology NewYork: Basic Books 653-682.

42. Roberts D, Bachen C (1981) Mass communication effects. The uses of mass communication 32: 307-356.

43. Harris RJ (1994) Effects of sex in the media. Media effects: Advances in theory and research, 505 Hillsdale, NJ: Lawrence Erlbaum Associates, United Kingdom.

44. Jeffres LW (1997) Mass media effects. Prospect Heights IL: Waveland Press USA.

45. Jeffres LW, Neuendorf KA, Atkin D (1999) Spirals of silence: Expressing opinions when the climate of opinion is unambiguous. Political Communication 16: $115-131$.

46. Adhikari DN (2006) Media and democracy in Nepal: A case for public-oriented journalism. Georgia Southern University Press, Statesboro, USA.

47. Wimmer RD, Dominick JR (2009) Mass media research: An introduction (10thedn), Thomson Wadsworth, Singapore.

48. Wimmer RD, Dominick JR (2010). Mass media research: AN introduction Thomson Wadsworth, Singapore.

49. Buddenbaum JM, Novak KB (2005) Applied communication research. Surjeet Publication. New Delhi, India.

50. Prajapati U (2011) Influence of foreign policy on Nepalese press: A case study on coverage of Tibetan protest in Nepal. University of Oslo, Norway. 